\title{
ANALISIS PERENCANAAN KEBUTUHAN TENAGA DOKTER OLEH DINAS KESEHATAN KOTA PEKANBARU
}

\author{
Pebriana Marlinda \\ Universitas Lancang Kuning \\ Email: pebrianamarlinda@unilak.ac.id
}

\begin{abstract}
Abstrak
Tulisan ini membahas proses perencanaan kebutuhan tenaga dokter yang dilaksanakan oleh Dinas Kesehatan Kota Pekanbaru. Sejauh ini langkah inventarisasi dalam proses perencanaan yang dilakukan hanya sebatas pendataan jumlah dan kualifikasi tenaga dokter saja, belum sampai pada kegiatan analisis dan pemetaan. Disamping itu, metode yang digunakan belum baku, sehinga jumlah dokter melebihi standar nasional, tetapi kualifikasinya tidak tepat dan distribusi tidak merata.

Penelitian ini merupakan penelitian kualitatif yang akan memahami dan menggali secara mendalam data-data sekunder yang berupa dokumen-dokumen yang berkaitan dengan topic penelitian, serta data-data primer yang diperoleh dari wawancara dengan informan penelitian yaitu: Kepala Dinas Kesehatan, Kepala Subbagian umum dan Kepegawaian, Kepala Seksi Bagian Pelayanan Kesehatan Dasar dan Rujukan.Untuk menganalisa perencanaan kebutuhan tenaga dokter yang dilaksanakan oleh Dinas Kesehatan Kota Pekanbaru, penulis menggunakan teori yang dikemukakan oleh Noatmodjo (2003:24) yakni: inventarisasi, perkiraan (peramalan), penyusunan rencana dan, monitoring dan evaluasi.

Keseimpulan dari hasil penelitian ini adalah perencanaan kebutuhan tenaga dokter yang dilakukan oleh Dinas Kesehatan Kota Pekanbaru melalui langkah-langkah perencanaan yaitu: inventarisasi, perkiraan (peramalan), penyusunan rencana dan, monitoring dan evaluasi. Namun perlu adanya penguatan disetiap langkah-langkahnya dengan adanya komitmen resmi dari pemerintah Kota Pekanbaru, berupa pembuatan Master Plan Kesehatan, Standar Pelayanan Minimum (SPM), pembentukan bagian khusus yang melakukan perencanaan dan Standar Operasional Pelaksanaan (SOP).
\end{abstract}

Kata kunci: Analisis Perencanaan Kebutuhan Tenaga dokter.

This study addresses the need of medical doctors planning process undertaken by theHealth Deparment in Pekanbaru City. So far inventory step in the planning process under taken only limited data collection and the number of qualified doctorsonly, not to the activity analysis and mapping. In addition, the method that used by health office in Pekanbaru City is not standard, so that the number of doctors exceeds national standards, but it is not appropriate qualifications and uneven distribution.

This study is a qualitative research to seeks and understand deeply the secondary data from the documents which related the topics, as well as the primary data obtained from interviews with informant of the research as: Chief of medical department, The head of Human resources division and Chief of health section of Health Services and Referral Association.To analyze the planning needs of medical doctors conducted by the Health Departement Pekanbaru city, the author uses the theory proposed by Noatmodjo (2003: 24), namely: inventory, estimate (forecasting), and the planning, monitoring and evaluation.

The conclusion of this research is the planning of the medical doctors' need which has done by health department of Pekanbaru had through steps as follows: inventory, forecasting (estimate), monitoring and evaluation. But there should be strengthened in every steps and also commitment from pekanbaru government, as preparation of the health master plan, minimum standard services, establishes a special a department of planning and standard operational procedure.

Keyword: Planning Needs Analysis of Medical doctors. 


\section{PENDAHULUAN}

Keberhasilan pembangunan suatu negara dapat terlihat dari Indeks Pembangunan Manusianya (IPM) yang di ukur melalui 3 (tiga) indikator yaitu kesehatan, pendidikan dan daya beli. Namun dari indikator tersebut, indikator kesehatan merupakan aspek terpenting. Hal ini disebabkan karena kesehatan merupakan aset yang sangat menentukan keberlangsungan hidup manusia, hanya dengan tubuh yang sehatlah manusia dapat mengikuti pendidikan dan meningkatkan taraf hidupnya sehingga berdampak terhadap peningkatan daya beli. Pembangunan pada aspek kesehatan bertujuan untuk meningkatkan kesadaran, kemauan, dan kemampuan hidup sehat bagi setiap orang agar terwujud derajat kesehatan masyarakat yang optimal yang ditandai oleh penduduknya berperilaku hidup sehat dan dalam lingkungan yang sehat, memiliki kemampuan untuk menjangkau pelayanan kesehatan yang bermutu secara adil dan merata, serta memilki derajat kesehatan yang optimal di seluruh wilayah Republik Indonesia. Prioritas pembangunan ini diberikan pula kepada daerah terpencil, pemukiman baru, wilayah perbatasan dan pulau-pulau terluar. (Depkes RI, 2008).

Langkah konkrit yang diambil pemerintah dalam rangka mewujudkan pembangunan kesehatan salah satunya dengan dikeluarkannya Peraturan Pemerintah Nomor 32 tahun 1996 tentang Tenaga Kesehatan bahwa pengadaan dan penempatan tenaga kesehatan dilaksanakan untuk memenuhi kebutuhan tenaga kesehatan yang merata bagi masyarakat. Perencanaan nasional tenaga kesehatan ini disusun dengan memperhatikan jenis pelayanan yang dibutuhkan, sarana kesehatan, serta jenis dan jumlah yang sesuai. Sebagai tindak lanjut dari Peraturan Pemerintah No. 32 Tahun 1996 Tentang Tenaga Kesehatan tersebut, maka dikeluarkanlah beberapa Keputusan Menteri Kesehatan (Kepmenkes) yaitu Kepmenkes No. 850/Menkes/SK/XII/2000 Tahun 2000 Tentang Kebijakan Perencanaan Tenaga Kesehatan untuk meningkatkan kemampuan para perencanan pemerintah, masyarakat, dan semua profesi disemua tingkatan. Selanjutnya Kepmenkes No. 81/Menkes/SK/I/2004 Tahun 2004 mengatur tentang Pedoman Penyusunan Perencanaan Sumberdaya Kesehatan di tingkat provinsi, kabupaten/kota, serta rumah sakit. Pada Kepmenkes tersebut disediakan pula daftar tentang metode perencanaan tenaga kesehatan untuk dipilih sesuai dengan kebutuhan.

Dalam rangka mendukung pemerintah pusat dalam mewujudkan pembangunan nasional, pemerintah Kota Pekanbaru melalui Peraturan Walikota Pekanbaru No. 18 tahun 2008 tentang Rincian, Fungsi, dan Tata Kerja Dinas di Lingkungan Pemerintah Kota Pekanbaru Provinsi Riau, termasuk Dinas Kesehatan Kota Pekanbaru dengan visi yaitu menujudkan " Masyarakat sehat, mandiri dan berkeadilan di Kota Pekanbaru". Agar visi tersebut dapat terealisasi dengan baik maka Dinas Kesehatan Kota Pekanbaru menyusun misi Dinas Kesehatan Kota Pekanbaru yakni sebagai berikut:

1. Menetapkan manajemen kesehatan yang dinamis dan akuntabel;

2. Meningkatkan derajat keshatan masyarakat melalui pemberdayaan masyarakat dan swasta;

3. Melindungi kesehatan masyarakat dengan tersedianya yang paripurna dan berkeadilan;

4. Meningkatkan ketersediaan dan pemerataan sumberdaya tenaga kesehatan.

Dalam melaksanakan tanggungjawab ini Dinas Kesehatan Kota Pekanbaru dibantu oleh unit pelayanan teknis yaitu 5 (lima) puskesmas rawat inap, 15 (lima belas) puskesmas rawat inap,34 (tiga puluh empat) unit puskesmas pembantu yang tersebar di 12 (tiga belas) kecamatan yang ada di Kota Pekanbaru. Berikut ini jumlah penduduk, ketersediaan rumah sakit dan puskesmas di Kota Pekanbaru. 
Tabel 1.1.Jumlah Puskesmas dan Rumah Sakit Per-Satuan Penduduk Tahun 2011 menurut Kecamatan-Kota Pekanbaru

\begin{tabular}{|c|c|c|c|c|c|c|}
\hline \multirow[b]{2}{*}{ No } & \multirow[b]{2}{*}{ Kecamatan } & \multirow[b]{2}{*}{$\begin{array}{l}\text { Jumlah } \\
\text { Penduduk }\end{array}$} & \multicolumn{2}{|c|}{ Puskesmas } & \multicolumn{2}{|l|}{$\begin{array}{c}\text { Rumah } \\
\text { Sakit }\end{array}$} \\
\hline & & & Jumlah & Rasio & Jumlah & Rasio \\
\hline 1. & Bukit Raya & 92.395 & 1 & 0,01 & 1 & 0,01 \\
\hline 2. & Marpoyan Damai & 126.355 & 2 & 0,02 & 6 & 0,05 \\
\hline 3. & Tampan & 170.543 & 3 & 0,02 & 1 & 0,006 \\
\hline 4. & Sukajadi & 47.420 & 2 & 0,04 & 4 & 0,08 \\
\hline 5. & Pku Kota & 25.193 & 1 & 0,04 & 3 & 0,12 \\
\hline 6. & Sail & 21.550 & 1 & 0,05 & 4 & 0,19 \\
\hline 7. & Lima Pulah & 41.549 & 1 & 0,02 & 0 & 0 \\
\hline 8. & Tenayan Raya & 123.799 & 2 & 0,02 & 0 & 0 \\
\hline 9. & Senapelan & 36.625 & 1 & 0,03 & 1 & 0,03 \\
\hline 10. & Rumbai Pesisir & 65.036 & 2 & 0,03 & 0 & 0 \\
\hline 11. & Rumbai & 64.961 & 3 & 0,05 & 0 & 0 \\
\hline 12. & Payung Sekaki & 87.038 & 1 & 0,01 & 2 & 0,02 \\
\hline & Jumlah & 902.464 & 19 & 0,02 & 22 & 0,02 \\
\hline
\end{tabular}

Sumber: RPJMD Kota Pekanbaru Tahun 2012-2017.

Berdasarkan RPJMD Kota Pekanbaru tahun 2012-2017 menyebutkan bahwa sarana dan prasarana kesehatan di Kota Pekanbaru masih terbatas dan memerlukan pembangunan rumah sakit di 5 kecamatan yaitu di Kecamatan Tampan, Lima Puluh, Tenayan Raya, Rumbai dan Rumbai Pesisir. Selain itu, jika berbicara masalah aspek kesehatan maka masalah yang terpenting adalah tenaga dokter. Karena butuh waktu lama untuk membentuk seorang tenaga dokter yang ahli di bidangnya. Sedangkan masalah sarana prasarana ataupun dana itu masih bisa di cari dan dibentuk dalam waktu singkat.

Masalah tenaga dokter tidak hanya sebatas pemenuhan jumlah formasi atau kuantitas (jumlah) saja, tetapi lebih kepada kualifikasi tenaga dokter yang tersedia, serta kesesuaian antara keahlian dari tenaga dokter dengan kondisi atau kebutuhan daerah tempat mereka ditempatkan. Berdasarkan data dari RPJMD Kota Pekanbaru tahun 2012-2017 menyebutkan bahwa jumlah tenaga dokter di Kota Pekanbaru pada tahun 2010 berjumlah 570 dan meningkat menjadi 979 pada tahun 2011. Untuk lebih jelasnya mengenai ketersediaan tenaga dokter di Kota Pekanbaru dari tahun 2007-2011 dapat dilihat pada Grafik berikut ini.

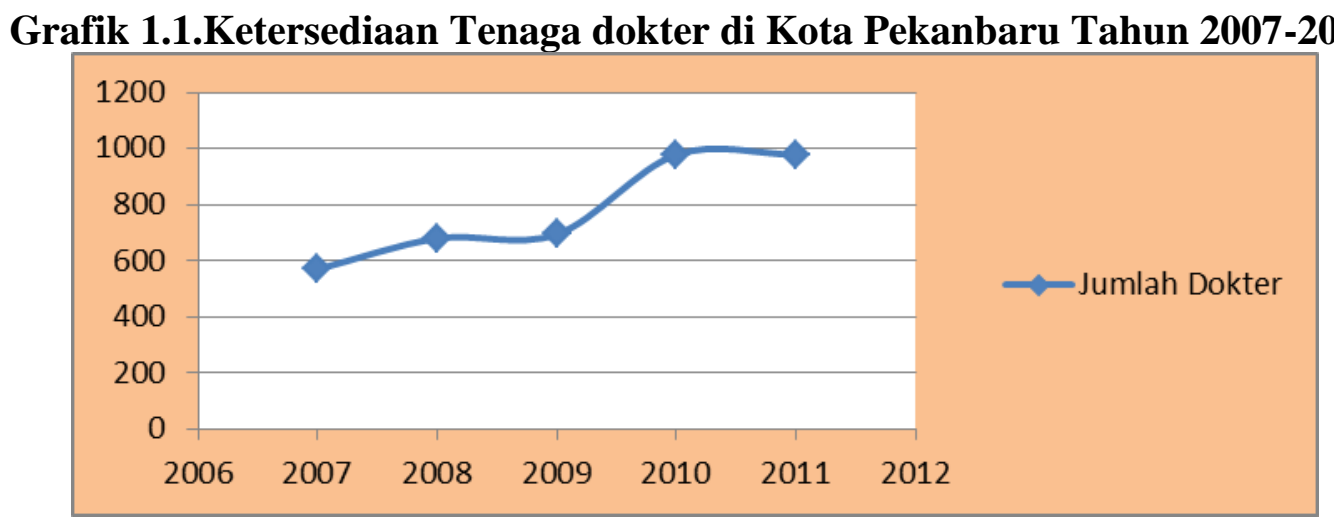

Sumber : BPS Kota Pekanbaru yang diolah kembali 
Dari grafik di atas dapat terlihat bahwa ada peningkatan jumlah ketersediaan tenaga dokter di Kota Pekanbaru setiap tahunnya, meskipun ada sedikit penurunan jumlah pada tahun 2011. Namun peningkatan jumlah ini bukan berarti jumlah tenaga dokter yang tersedia sudah ideal atau sudah memenuhi syarat dan ketentuan nasional. Untuk lebih jelasnya mengenai kebutuhan tenaga dokter perkecamatan di Kota Pekanbaru yang sesuai dengan standar nasional dalam setiap 100.000 penduduk dapat dilihat pada grafik berikut ini.

Grafik 1.2. Perbandingan Ketersediaan Tenaga dokter per-Kecamatan di Kota Pekanbaru Dengan Jumlah dokter yang Dibutuhkan per-100.000 Penduduk Sesuai Dengan Standar Nasional

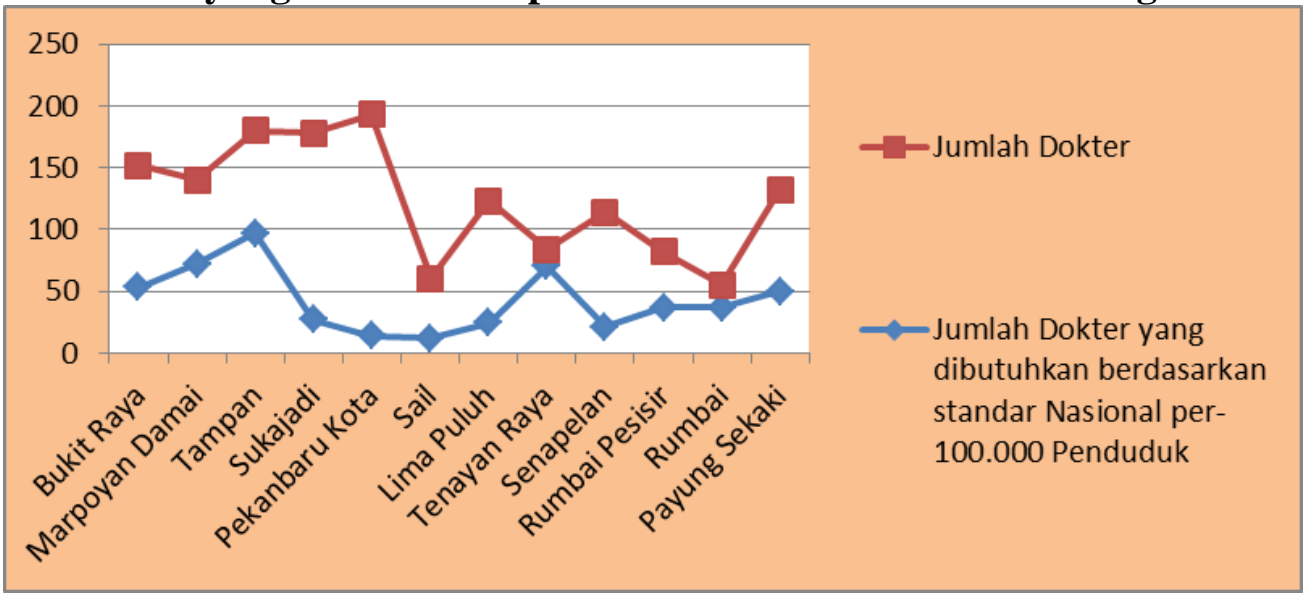

Sumber : RPJMD Kota Pekanbaru Tahun 2012-2017 yang diolah kembali.

Dari grafik di atas terlihat bahwa jumlah dokter yang tersedia per-kecamatan di Kota Pekanbaru telah melebihi standar nasional ketersediaan tenaga dokter per-100.000 penduduk. Namun, pendistribusiannya belum merata pada umumnya penumpukan jumlah tenaga dokter terdapat di daerah perkotaan. Kondisi yang terjadi di Kota Pekanbaru ini sama dengan masalah nasional. Menurut hasil penelitian Departemen Kesehatan, terjadinya penumpukan tenaga kesehatan di wilayah tertentu (daerah perkotaan) mengakibatkan pelayanan kesehatan di kabupaten terutama daerah yang tidak diminati dan daerah terpencil menjadi tidak optimal sehingga derajat kesehatan masyarakat di daerah akan semakin rendah.

Dengan jumlah tenaga dokter yang besar dan melebihi standar nasional seharusnya kualitas pelayanan kesehatan di Kota Pekanbaru sudah baik dan memenuhi SPM (Standar Pelayanan Minimun). Namun yang terjadi $70 \%$ pelayanan kesehatan dasar Kota Pekanbaru di bawah Standar Pelayanan Minimum (SPM). Misalnya, penanganan penderita penyakit TBC TBA yang berada pada angka 33,87 \% yang seharusnya mencapai angka $100 \%$.

Di samping masalah distribusi dokter yang belum merata, masalah lain terkait dengan ketersediaan tenaga dokter di Kota Pekanbaru yaitu mengenai kualifikasi dokter yang belum sesuai dengan kebutuhan daerah. Berdasarkan data dari Badan Pusat Statistik (BPS) Kota Pekanbaru kasus penyakit yang paling banyak terjadi di Kota Pekanbaru 2 (dua) tahun terakhir yaitu kasus penyakit Infeksi Saluran Pernapasan Akut (ISPA). Kasus kondisi ini tidak terlepas dari kasus kebakaran hutan di Provinsi Riau yang telah menjadi daerah langganan kebakaran hutan setiap tahunnya. Hampir seluruh daerah di Provinsi Riau terkena dampak dari kebakaran hutan ini, yang berupa kabut asap termasuk Kota Pekanbaru.

Penyakit ISPA yang menyerang masyarakat Kota Pekanbaru akibatkan kebakaran hutan, hanya bersifat ringan seperti batuk dan pilek jika ditangani dengan baik. Namun, jika dibiarkan tanpa mendapat pengobatan bisa menjadi pneumonia atau radang paru dan bahkan bisa menyebabkan kematian. Sejauh ini, kematian pada bayi dan anak-anak akibat ISPA temasuk tinggi yaitu mencapai satu dari empat kasus 
kematian. Oleh karena itu, ISPA merupakan penyebab kematian terbesar setelah pneumonia yang terjadi pada bayi berumur kurang dari dua bulan. Selain ISPA, efek buruk kabut asap terhadap kesehatan dalam waktu 4 sampai 6 tahun kedepan akan membuat kemunduran daya pikir, intelegensi dan kanker.

Mengingat dampak jangka panjang yang ditimbulkan oleh kabut asap terhadap kesehatan masyarakat, hendaknya pemerintah Kota Pekanbaru lebih serius dalam menyikapi masalah ini. Salah satunya yaitu, melalui perencanaan kesehatan Kota Pekanbaru yang tepat dan sesuai dengan kebutuhan, khususnya pada aspek tenaga kesehatan yang akan menangani permasalahan kesehatan yang terjadi di setiap kecamatan yang terdapat di Kota Pekanbaru.

Penelitian-penelitian tentang tenaga kesehatan telah banyak dilakukan, hasil penelitian terdahulu yang relevan dapat dijadikan perbandingan oleh peneliti dalam memahami aspek tenaga kesehatan. Penelitian-penelitian terdahulu tersebut dapat menegaskan perbedaan penelitian yang peneliti lakukan dengan penelitian-penelitian terdahulu yang sudah ada. Penelitian terdahulu tentang tenaga kesehatan antara lain telah dilakukan oleh Herman Mubasyir Hasanbasri (2008) yang menunjukkan bahwa kebijakan penempatan tenaga kesehatan belum berpihak pada Puskesmas sangat terpencil masih bersifat umum dan berorientasi pada jangka pendek. Sedangkan penelitian yang dilakukakan oleh Misnaniarti (2010) menunjukkan bahwa perlu adanya peninjauan ulang sistem perekrutan tenaga kesehatan agar sesuai dengan kebutuhan.

Penelitian yang penulis lakukan berbeda dengan beberapa penelitian tentang tenaga kesehatan yang telah dilakukan sebelumnya. Penelitian ini lebih fokus pada tenaga dokter yang merupakan bagian dari tenaga kesehatan. Aspek yang dilihat dalam penelitian ini yaitu perencanaan kebutuhan dokter yang dilaksanakan oleh Dinas Kesehatan Kota Pekanbaru.Selama ini perencanaan kebutuhan tenaga dokter yang dilakukan belum optimal dan terkesan formalitas saja. Penulis menemukan masalah dalam proses perencanaan tersebut, adapun masalah yang dimaksud yakni sebagai berikut:

1. Langkah inventarisasi yang dilaksankan dalam proses perencanaan kebutuhan tenaga dokter di Kota Pekanbaru hanya sebatas pendataan jumlah tenaga dokter saja belum sampai pada tahap analisis dan pemetaan, sehingga data yang tersedia mengenai kondisi tenaga dokter saat ini (pada waktu perencanaan dilaksanakan) hanya mengenai jumlah dan kualifikasi saja. Hal ini mengakibatkan data-data yang berkaitan dengan perencanaan kebutuhan tenaga dokter di Kota Pekanbaru tidak valid. Keseluruhan dari langkah inventarisasi ini akan menghasilkan peta tenaga dokter yang tersedia di Kota Pekanbaru. Dengan tidak adanya peta tenaga dokter ini, mengakibatkan tidak diketahui apakah jumlah tenaga dokter yang tersedia saat ini telah mencukupi secara jumlah, kualifikasi dan apakah tenaga dokter yang tersedia tersebut sesuai dengan status kesehatan masyarakat di Kota Pekanbaru.

2. Metode yang digunakan belum baku, sehingga metode untuk menghitung kebutuhan tenaga dokter di Kota Pekanbaru belum jelas. Hal ini mengakibatkan kondisi ketersediaan tenaga dokter di Kota Pekanbaru telah melebihi standar nasional kebutuhan tenaga dokter per-kecamatan, tetapi kualifikasinya tidak tepat dan pendistribusian tenaga dokter ini belum merata. Berdasarkan masalah dala proses perencanaan tenaga dokter di Kota Pekanbaru di atas, maka penulis tertarik untuk melakukan kajian mengenai langkah-langkah yang dilakukan oleh Dinas Kesehatan Kota Pekanbaru dalam proses perencanaan tenaga dokter dengan judul "Analisis Perencanaan Kebutuhan Tenaga dokter Oleh Dinas Kesehatan Kota Pekanbaru."

Andrew E. Sikula (1981:145) mengemukakan bahwa: "Human resource of manpower planning has been defined as the process of determining manpower requirements and tehe means for meeting those requirements in order to carry out the integrated plans of the organization." Artinya "Perencanaan sumber daya manusia atau perencanaan tenaga kerja didefinisikan sebagai proses menentukan kebutuhan tenaga kerja dan berarti mempertemukan kebutuhan tersebut agar pelaksanaannya berinteraksi dengan rencana organisasi." Dalam proses menentukan kebutuhan tenaga kerja yang sesuai dengan kebutuhan organisasi harus dilakukan pemetaan tentang sumberdaya manusia seperti apa yang organisasi butuhkan untuk 
mencapai tujuan organisasi. Setelah itu organisasi harus tahu seperti apa kriteria sumberdaya manusia yang saat ini dimiliki organisasi.

Kegiatan perencanaan merupakan suatu langkah antisipasi kemungkinan-kemungkinan yang akan terjadi di masa depan. Dengan adanya perencanaan suatu organisasi dapat mengatur ritme pergerakan pegawai dalam organisasi. Jika beban kerja melebihi jumlah pengawai yang tersedia, maka dapat dilakukan perekrutan pegawai. Tidak hanya itu, organisasi juga dapat melakukan promosi untuk pegawainya dari satu posisi ke posisi yang lebih strategis, memindahkan pegawai dari satu posisi ke posisi yang lain.

Langkah-langkah Perencanaan Pegawai

Langkah-langkah perencanaan pegawai merupakan suatu proses untuk menentukan kebutuhan akan tenaga kerja untuk waktu yang akan datang dan perencanaan tindakan dalam memenuhi kebutuhan tersebut. Sebagaimana yang dikemukakan oleh Moekijat (1991 : 69) proses perencanaan tenaga kerja meliputi 3 (tiga) unsur pokok, yaitu:

1. Daftar tenaga kerja saat ini. Daftar pegawai yang ada sekarang akan menggambarkan karakteristek pegawai tersebut, baik secara kualitatif maupun secara kuantitatif.

2. Ramalan tenaga kerja, adalah tenaga kerja yang diperlukan untuk waktu yang akan datang yang digambarkan baik disegi jumlah maupun disegi kualitas (kecakapan, tingkat pendidikan, dan pengalaman).

3. Rencana tenaga kerja, yakni rencana tindakan untuk menjembatani celah (Gap) anatara ramalan kebutuhan tenaga kerja dengan daftar tenaga kerja yang saat ini.

Langkah-langkah dalam proses perencanaan yang dikemukakan oleh Moekijat (1991:69) diatas menekankan bahwa, gambaraan ketersediaan pegawai saat ini akan memberikan kontribusi dalam penentuan karakteristik pegawai yang dibutuhkan dimasa akan datang, baik disegi jumlah maupun disegi kualitas. Hal ini diyakini dapat membatu dalam kegiatan peramalan kebutuhan pegawai sehingga menghasilkan rencana kebutuhan pegawai yang tepat dalam organisasi di masa akan datang agar organisasi mampu untuk mencapai tujuan organisasi yang telah ditetapkan sebelumnya.

Menurut Milkovich dan Broudreau (1991 : 146) ada 3 (tiga) fase perencanaan pegawai yaitu:

1. Analisis Kebutuhan

2. Analisis Suplai

3. Keputusan terhadap kecocokan (1) dan (2) menyelaraskan.

Berikut ini penjelasan lebih lanjut mengenai 3 (tiga) fase perencanaan pegawai yang dikemukakan oleh Milkovich dan Broudreau (1991 : 146) yaitu sebagai berikut.

1.Analisis kebutuhan, terdiri dari 2 unsur pokok, yaitu:

a.Kondisi organisasi. Kondisi organisasi terdiri dari rencana-rencana perusahaan tentang pemasaran, keuangan operasional, dan teknologi yang digunakan. Semua rencana-rencana ini harus dipunyai oleh organisasi yang merupakan "organizational bussiness plan atau organizational strategic planning."

b.Peramalan kebutuhan. Hal-hal yang diperlukan dalam menentukan peramalan kebutuhan antara lain adalah jumlah pegawai, pengamalan, kemampuan, ras, dan biaya yang dibutuhkan unsur lain yang masih dianggap penting.

2.Analisis suplai. Analisis ini memfokuskan pada dua analisis, yaitu: suplai internal dan suplai eksternal. a.Suplai internal. Kegiatan analaisis suplai internal ini pada prinsipnya merupakan kegiatan sederhana, karena analisis ini dihadapkan pada menentukan jumlah pegawai yang bekerja saat ini. Dari jumlah pegawai yang ada tersebut kemudian dibuat estimasi berapa orang yang tetap bekerja pada pekerjaan tertentu, berapa orang yang pindah ke pekerjaan lain melalui promosi, demosi, dan transfer. Berapa orang yang akan keluar dari suatu organisasi misalnya pensiun, diberhentikan, atau mengundurkan diri.

b.Suplai eksternal. Kegiatan ini yaitu kegiatan yang memfokuskan pada organisasi luar.

c.Keputusan terhadap kecocokan (1) dan (2) 
Keputusan yang akan diambil adalah mengatasi maslah (gap) yang terjadi antara (1) dan (2). Bila pegawai surplus, maka keputusan perusahaan di masa mendatang adalah lay offs dan bila pegawai shortages maka keputusan yang diambil adalah meng-hires.

Notoatmodjo (2003:24) mengemukakan 4 (empat) langkah-langkah perencanaan sumber daya manusia yaitu sebagai berikut:

1.Inventarisasi

2.Perkiraan (peramalan)

3.Penyusunan rencana

4.Monitoring dan Evaluasi.

Langkah-langkah perencanaan sumber daya manusia diatas, dalam prosesnya memperhatikan atau meperhitungkan lingkungan eksternal dan internal dari organisasi. Ini dilakukan untuk mengetahui ancaman atau peluang yang akan dihadapi organisasi dimasa akan datang. Dengan mengetahui hal tersebut organisasi dapat menggambarkan kemungkinan-kemungkinan yang akan terjadi, sehingga organisasi dapat mengambil keputusan yang tepat dan mampu mempertahankan eksistensi organisasinya.

Dari 3 (tiga) model perencanaan pegawai, maka penulis dapat menyimpulkan ada dua unsur pokok yang penting dalam perencanaan pegawai, yaitu:

1.Kebutuhan pegawai

2.Suplai pegawai

Kedua unsur ini perlu mendapat perhatian agar organisasi dapat meprediksikan rencana kebutuhan pegawai yang sesuai baik kualitas maupun kuantitas untuk kemudian menetukan sumber-sumber pemenuhan kebutuhannya.

Dalam analisis kebutuhan pegawai ada dua hal yang perlu diperhatikan yaitu:

1.Penyebab timbulnya kebutuhan

2.Teknik perencanaan

Setelah membuat proyeksi kebutuhan pegawai dimasa yang akan datang, kegiatan selanjutnya adalah analisis suplai pegawai atau pemenuhan lowongan yang yang diproyeksikan. Analisi ini berasal dari dua sumber yaitu: Suplai internal dan eksternal. Suplai internal melihat persediaan pegawai yang ada sekarang kemudian diprediksi untuk dipromosi, dipindahkan atau demosi.

\section{METODE}

Penelitian yang dilakukan bermaksud untuk menganalisa perencanaan kebutuhan tenaga dokter oleh Dinas Kesehatan Kota Pekanbaru. Berdasarkan karakteristik tujuan penelitian yang ingin diperoleh tersebut, maka peneliti menganalisa data yang berhubungan dengan perencanaan tenaga dokter di Kota Pekanbaru. Oleh karena itu, metode yang digunakan dalam penelitian ini adalah metode deskriptif dengan pendekatan kualitatif.

Penelitian kualitatif memiliki kekuatan terutama berasal dari pendekatan induktif yang fokus pada situasi yang spesifik atau orang serta penekanan terhadap kata-kata bukan angka. Penelitian kualitatif merupakan penelitian yang mampu untuk mendeskripsikan secara terperinci dalam mengungkap fenomena-fenomena yang terjadi dilapangan. Pada dasar Penelitian kualitatif lebih menekankan pada proses dari pada hasil dan bersifat deskriptif. Disamping itu hanya pendekatan kualitatif yang mampu untuk menjelaskan dan mengambarkan sebuah sitem. Tidak hanya itu saja penelitian kualitatif lebih mudah menyesuaikan dengan kondisi yang terjadi dilapangan dan keberdaan teori dalam penelitian kualitatif tidak untuk diuji dalam rangka mencari kebenaran. Namun keberadaan teori dalam penelitian kualitatif dapat dikembangkan berdasar data yang di telah diperoleh dilapangan. 


\section{HASIL DAN PEMBAHASAN}

Inventarisasi

Kegiatan inventarisasi persediaan SDM yaitu menelaah dan menilai SDM yang ada atau tersedia saat ini (jumlah, kemampuan, keterampilan dan potensi pengembangan) serta menganalisis penggunaan sumberdaya sekarang in Notoatmodjo (2003). Hal ini sejalan dengan pendapat Manullang (2004) bahwa dengan inventarisasi persediaan SDM nantinya akan digunakan sebagai bahan pengambilan keputusan yang tepat untukpromosi, latihan, pendidikan dan mutasi SDM dalam organisasi serta diketahui keadaan kekurangan atau kelebihan SDM yang dibutuhkan atau rencana kebutuhan SDM di masa akan datang.

Dari pengertian diatas bila dikaitkan dengan tenaga dokter dapat diketahui bahwa dalam langkah inventarisasi kegiatan yang dilakukan berkaitan dengan pendataan jumlah, kualifikasi dan potensi pengembangan tenaga dokter yang tersedia saat ini. Tidak sampai disitu saja, bahwa dalam tahapan ini harus dilakukan analisis penggunaan tenaga dokter saat ini. Iinformasi yang telah diperoleh ini dapat menjadi dasar untuk menentukan kemampuan tambahan yang diperlukan tenaga dokter masa mendatang yang mungkin belum diperlukan pada saat ini.

Pendataan tenaga dokter yang tersedia di Kota Pekanabru berasal dari laporan setiap puskesmas yang diserahkan ke pada Dinas Kesehatan, tepatnya kepada Sub Bagian Umum dan Kepegawaian. Laporan ini biasanya diserahkan di akhir tahun (per-desember). Laporan mengenai ketersediaan tenaga dokter di Kota Pekanbaru per-puskesmas ini akan diolah yang akhirnya akan berbentuk data inventarisasi tenaga dokter. Berikut data inventarisasi tenaga dokter yang tersedia per-puskesmas di Kota Pekanbaru per-Desember 2013.

Tabel 4.1.Tabel Inventarisasi Tenaga dokter per-Puskesmas di Kota Pekanbaru perDesember 2013

\begin{tabular}{|l|l|l|l|l|}
\hline No. & Unit Kerja (Puskesmas) & dr. Spesialis & dr. Umum & dr. Gigi \\
\hline 1. & Langsat & & 3 & 3 \\
\hline 2. & Melur & 1 & 4 & 3 \\
\hline 3 & Payung Sekaki & & 4 & 1 \\
\hline 4 & Limapuluh & & 2 & 3 \\
\hline 5 & PB. Kota & 4 & 2 \\
\hline 6 & Senapelan & 3 & 2 \\
\hline 7 & Rumbai & & 2 & 3 \\
\hline 8 & Uman Sari & & 2 & 1 \\
\hline 9 & Rumbai Bukit & 3 & 1 \\
\hline 10 & Garuda & & 3 & 2 \\
\hline 11 & Harapan Raya & 4 & 2 \\
\hline 12 & Rejosari & 4 & 2 \\
\hline 13 & Sail & & 2 & 3 \\
\hline 14 & Sidomulyo & 5 & 2 \\
\hline 15 & Simpang Baru & 5 & 1 \\
\hline 16 & Rawat Inap Simpang Tiga & & 5 & 1 \\
\hline 17 & Rawat Inap Tenayan Raya & 5 & 5 & 1 \\
\hline 18 & Rawat Inap Sidomulyo & 1 & 6 & 1 \\
\hline 19 & Rawat Inap Karya Wanita & 1 & 5 & 2 \\
\hline 20 & Rawat Inap Muara Fajar & 1 & 6 & 1 \\
\hline \multicolumn{2}{|l|}{ Jumlah } & & \\
\hline
\end{tabular}


Berdasarkan SK Mendagri No. 23 Tahun 1994, Tentang Pedoman Organisasi dan Tata Kerja Puskesmas menyebutkan bahwa standar tenaga dokter di tingkat puskesmas terdiri dari: 2 (dua) orang tenaga dokter untuk puskesmas non DTP, 3 (tiga) orang tenaga dokter untuk puskesmas DTP dan untuk puskesmas pembantu tidak ditentukan standar kebutuhannya. Jika menilai jumlah tenaga dokter perpuskesmas di Kota Pekanbaru dengan standar jumlah tenaga dokter di puskesmas berdarakan SK Mendagri No.23 Tahun 1994 Tentang Pedoman Organisasi dan Tata Kerja Puskesmas, maka jumlah tenaga dokter yang ada di Kota Pekanbaru telah mencukupi bahkan melebihi standar kebutuhan tenaga dokter per-puskesmas di Kota Pekanbaru. Namun jika menilai ketersediaan jumlah tenaga dokter di Kota Pekanbaru dengan standar Indikator Indonesia Sehat tahun 2010 menurut jenis tenaga kesehatan per100.000 penduduk, maka jumlah tenaga dokter yang tersedia belum mencukupi kebutuhan tenaga dokter per-100.000 penduduk. Sebagaimana yang dinyatakan dalam SK Mendagri No. 23 Tahun 1994, Tentang Pedoman Organisasi dan Tata Kerja Puskesmas bahwa jumlah kebutuhan tenaga dokter per-100.000 berjumlah 57 (lima puluh tujuh) dengan kualifikasi: 6 (enam) dokter spesialis, 40 (empat puluh) dokter Umum dan 11 (sebelas) dokter Gigi. Sedangkan tenaga dokter yang tersedia di Kota Pekanbaruhanya berjumlah 103 (103) tenaga dokter dengan jumlah penduduk 964.558 jiwa, yang terdiri dari 9 (sembilan) dokter Spesialis, 67 (enam puluh tujuh) dokter Umum dan 37 (tiga puluh tujuh) dokter Gigi. Mengacu pada standar kebutuhan tenaga dokter tersebut, seharusnya jumlah tenaga dokter yang dibutuhkan lebih kurang 549 (lima ratus empat puluh sembilan) tenaga dokter. Jadi Kota Pekanbaru masih kekurangan tenaga dokter sebanyak 446 (empat ratus empat puluh enam) tenaga dokter. Kekurangan yang ada hampir 4 (empat) kali lipat dari jumlah tenaga dokter yang tersedia. Fakta mengenai kekurangan tenaga dokter ini sangat bertolak belakang dengan data pada grafik 1.2. yang disajikan di bab I sebelumnya. Dimana pada data tersebut jumlah tenaga dokter per-Kecamatan di Kota Pekanbaru mencukupi bahkan melebihi standar nasional kebutuhan tenaga dokter per-100.000 penduduk di Kota Pekanbaru.

Perbedaan jumlah tenaga dokter yang sangat siknifikan ini sangat berpengaruh dalam pelaksanaan langkah inventarisasi, karena dalam langkah inventarisasi tidak sebatas pendataan jumlah ketersediaan tenaga dokter saja tetapi juga menganalisa penggunaan tenaga dokter dimasa lalu maupun saat ini. Kegiatan ini dimaksudkan untuk mempermudah pemetaan tenaga dokter, dan keseluruhan kegiatan ini membutuhkan data-data yang akurat. Dari uraian mengenai langkah inventarisari diatas, diketahui bahwa langkah inventarisasi meliputi kegiatan pendataan, penganalisaan dan pemetaan yang nantinya akan menghasilkan peta tenaga dokter. Namun, langkah inventarisari yang telah dilakukan oleh Dinas Kesehatan Kota Pekanbaru dalam rangka menginventarisai tenaga dokter di Kota Pekanbaru hanya sampai pada kegiatan pendataan ketersediaan tenaga dokter saja, belum sampai pada kegiatan penganalisaan dan pemetaan penggunaan tenaga dokter yang tersedia. Sehingga Dinas Kesehatan Kota Pekanbaru belum memiliki peta tenaga dokter Kota Pekanbaru.

Perkiraan (Peramalan)

Mengacuh pada hasil inventarisa yang telah dilakukan sebelumnya, maka langkah berikutnya dalam proses perencanaan kebutuhan tenaga dokter yaitu langkah perkiraan (peramalan). Perkiraan (peramalan) kebutuhan tenaga dokter ini berguna untuk memprediksi kebutuhan tenaga dokter dimasa datang yang mencukupi secara kuantitas (jumlah) dan mencukupi secara kualifikasi. Hal ini bertujuan agar mampu menyediakan tenaga dokter yang dapat menyelesaikan persoalan kesehatan dimana mereka ditempatkan.

Dalam langkah perkiraan (peramalan) membutuhkan informasi ketersediaan tenaga dokter saat ini, untuk mengidentifikasi kondisi kebutuhan tenaga dokter dimasa yang akan datang, yang tepat mencukupi kuantitas (jumlah) dan mencukupi secara kualifikasi. Proyeksi untuk masa yang akan datang tentu saja ada unsur ketidaktepatan. Namun, jika peramalan dilakukan oleh orang yang ahli dan dengan metode yang tepat, maka kemungkinan ketidak tepatan hasil perkiraan (peramalan) dapat diminimalisir. Sebagaiman yang dijelaskan pada latar belakang masalah penelitian bahwa jumlah tenaga dokter di Kota 
Pekanbaru melebihi standar nasional. Demikian pula jika dilihat jumlah tenaga dokter per-kecamatan yang ada di Kota Pekanbaru. Namun jika jumlah tenaga kesehatan yang tersedia di Kota Pekanbaru dibandingkan dengan standar jumlah tenaga dokter menurut indikator Indonesia Sehat 2010, maka jumlah tenaga dokter yang tersedia dibawah standar nasional.

Proses perkiraan tenaga dokter di Kota Pekanbaru diatas diketahui bahwa perkiraan (peramalan) yang dilakukan hanya memperhatikan sisi penawaran (suply) saja tanpa melihat sisi permintaan (demand) dan bersifat jangka pendek. Penulis berpendapat bahwa seharusnya perkiraan tenaga dokter di Kota Pekanbaru memperkirakan untuk jangka panjang. Hal ini disebabkan oleh tantangan lingkungan yang dihadapi oleh penduduk Kota Pekanbaru khususnya dan Provinsi Riau umumnya sangat membahayakan kesehatan untuk jangka panjang, agar rencana kebutuhan tenaga dokter yang dihasilkan dapat mencukupi kebutuhan tenaga dokter yang mampu untuk menyelesaikan kemungkinan permasalahan dimasa depan.

Penyusunan Rencana

Penyusunan rencana SDM dapat diartikan sebagai suatu proses menentukan kebutuhan akan tenaga kerja berdasarkan peramalan pengembangan, pengimplementasian, dan pengendalian kebutuhan tersebut yang berintegrasi dengan perencanaan organisasi agar tercipta jumlah pegawai, penempatan pegawai yang tepat dan bermanfaat dimasa akan datang. Berdasarkan Keputusan Menteri Kesehatan No. 81 Tahun 2004 terdapat tiga metode dalam penyususnan kebutuhan tenaga dokter terdiri dari metode rasio (ratio method), metode Daftar Susunan Pegawai (DPS) atau WISN (Work Load Indicator Staff Need). Metode rasio (rasio method) yaitu kegiatan membandingkan jumlah standar tenaga kesehatan terhadap jumlah penduduk di wilayah puskesmas dengan alasan paling cepat dan efektif mengingat adanya berbagai keterbatasan yang dihadapi seperti tenaga perencana yang tidak terlatih, data yang kurang lengkap, dan terbatasnya waktu perencanaan. Metode rasio ini lebih cocok untuk menghitung kebutuhan SDM kesehatan di tingkat wilayah (Depkes, 2004). Pada tabel rencana kebutuhan tenaga dokter di Kota Pekanbaru diatas kategori tenaga dokter yang disusun yaitu dokter Spesialis (Spesialis Dasar dan Spesialis Penunjang), dokter Umum dan Dokter Gigi. Namun, untuk kategori dokter Spesialis tidak ditentukan jumlah rencana kebutuhannya. Melihat hal ini, penulis berpendapat bahwa perencanaan yang dilakukan hanya formalitas saja. Karena dari awal metode yang digunakan untuk merencanakan kebutuhan tenaga dokter yaitu menggunakan metode (Work Load Indicator Staff Need), namun dokumen rencana kebutuhan tenaga dokter di Kota Pekanbaru yang ditemukan berupa data rasio. Menurut penulis metode yang tepat untuk menyusun rencna kebutuhan tenaga dokter per-puskesmas di Kota Pekanbaru yaitu menggunakan metode (Work Load Indicator Staff Need). Metode ini dirasa tepat mengingat laju pertumbahan pertumbuhan penduduk per-kecamatan di Kota Pekanbaru yang tidak merata, sehingga mengakibatkan kunjungan per-puskesmaspun tidak sama. Langkah penyusunan rencana kebutuhan tenaga dokter di Kota Pekanbaru yang telah dijelaskan sebelumnya menggambarkan bahwa metode penyusunan rencana yang diambil kurang tepat, sehingga langkah penyusunan rencana yang dilakukan kurang optimal. Kondisi ini disebabkan belum adanya komitmen resmi dan komunikasi yang baik dari pihakpihak yang terlibat dalam proses penyusunan rencana kebutuhan tenaga dokter ini.

Monitoring dan Evaluasi

Monitoring adalah suatu proses pengumpulan dan menganalisis informasi dari penerapan suatu program teramsuk mengecek secara reguler untuk melihat apakah kegiatan/program itu berjalan sesuai rencana sehingga masalah yang dilihat/ditemui dapat diatasi (WHO). Sedangkan evaluasi adalah suatu proses dari pengumpulan dan analisis informasi mengenai efektifitas dan dampak suatu program dalam tahap tertentu sebagai bagian atau keseluruhan dan juga mengkaji pencapaian program (WHO). Monitoring dan evaluasi tidak saja dilaksanakan untuk menilai berhasil atau tidaknya program yang dilaksanakan, namun evaluasi juga dapat dilakukan dalam proses perencanaan. Hal ini sejalan dengan pendapat Anderson dalam William 1994) yang menyatakan bahwa evaluasi merupakan kegiatan yang dimulai pada tahap perencanaan yaitu dengan menilai berbagai alternatif tindakan, evaluasi kemudian 
meluas melalui proses penerapan seraya kemajuan terus dimonitor melalui evaluasi formatif dan perbaikan-perbaikan dijalankan seperti yang telah disarankan, dan ini termasuk evaluasi sumatif tahap akhir untuk keseluruhan dampak program. Bahkan evaluasi pada tahap akhir tersebut seharusnya berwawasan kedepan; keberhasilan program ditonjolkan untuk diteruskan dan ditiru ditempat lain, serta kegagalan-kegagalan diidentifikasi agar jangan diulang lagi.

Dalam proses perencanaan kebutuhan tenaga dokter yang dilaksanakan oleh Dinas Kesehatan Kota Pekanbaru belum melakukan monitoring dan evaluasi dalam proses perencanaannya. Langkah evaluasi dan monitoring belum dapat diaksanakan karena tidak ada Standar Operasional Pelaksanaan (SOP) yang baku. Kondisi ini menyulitkan untuk melakukan monitoring dan evaluasi proses perencanaan yang dilaksankan. Padahal kegiatan evaluasi dan monitoring dalam proses perencanaan sangatlah penting, karena jika keputusan yang diambil kurang tepat maka dapat dilakukan perubahan-perubahan atau alternatif-alternatif penganti sebelum rencana kebutuhan tenaga dokter tersebut dilaksanakan. Jika hal ini dilaksanakan maka kemungkinan ketidaktepatan rencana yang dihasilkankan dapat diminimalisir.

\section{KESIMPULAN}

Dari hasil pembahasan yang telah disajikan sebelumnya dapat disimpulkan bahwa perencanaan tenaga dokter melalui 4 (empat) langkah yakni: inventarisasi, perkiraan (peramalan), penyusunan rencana dan, monitoring dan evaluasi telah dilaksanakan, kendatipun belum optimal. Adapun kondisi pelaksanaan langkah-langkah diatas sebagai berikut:

1. Langkah inventarisasi yang dilakukan hanya sebatas kegiatan pendataan tenaga dokter saja, belum sampai pada tahap penganalisaan dan pemetaan tenaga dokter di Kota Pekanbaru, sehingga tidak diperoleh peta kondisi tenaga dokter yang tersedia di Kota Pekanbaru. Sedangkan tujuan inventarisasi ini adalah untuk memperoleh peta tenaga dokter yang dimiliki.

2. Perkiraan tenaga dokter yang dilakukan belum optimal karena hanya memperhatikan sisi penawaran (suply) saja tanpa melihat sisi permintaan (demand), sehingga perkiraan yang dilakukan hanya mampu memperkirakan kebutuhan tenaga dokter untuk jangka pendek saja.

3. Langkah penyusunan rencana yang dilakukan belum optimal dikarenakan tidak adanya Master Plan Kesehatan, sehingga arah penggunaan metode penghitungan tenaga dokter yang dilakukan belum jelas.

4. Langkah evaluasi dan monitoring dalam perencanaan kebutuhan tenaga dokter di Kota Pekanbaru belum terlaksana dikarenakan belum adanya komitmen dari pihak yang terkait dalam proses perencanaan kebutuhan tenaga dokter, sehingga Standar Operasional Pelaksanaan (SOP) yang ada tidak baku.

\section{SARAN}

Dalam tulisan ini penulis menyarankan beberapa hal dalam proses perencanaan kebutuhan tenaga dokter yang dilaksanakan oleh Dinas Kesehatan Kota Pekanbaru berikut ini.

1. Perlu adanya komitmen yang kongkrit dari pihak-pihak terkait dalam hal perencanaan kebutuhan tenaga kesehatan, khususnya tenaga dokter dilingkungan pemerintah Kota Pekanbaru berupa pembuatan SOP (Standar Operasional Pelaksanaan) dan SPM (Standar Pelayanan Minimun) dalam bentuk peraturan walikota untuk mengukur kinerja SKPD, sehingga Dinas Kesehatan Kota Pekanbaru memiliki SOP (Standar Operasional Pelaksanaan) dan SPM (Standar Pelayanan Minimum) yang baku.

2. Perlu adanya Master Plan Kesehatan agar perencanaan kesehatan dalam hal ini tenaga dokter dapat lebih terarah dan jelas. 
3. Dibutuhkan pemahaman dan komunikasi yang solid dari pihak-pihak yang terkait agar perencanaan kebutuhan tenaga dokter yang dilakukan dapat dimaknai sebagai kebutuhan yang sangat penting untuk dilaksanakan, bukan sekadar tuntutan pembuatan laporan tahunan.

4. Perlu adanya pengkajian ulang Peraturan Walikota Pekanbaru No. 18 Tahun 2008 Tentang Rincian, Fungsi, dan Tata Kerja Dinas di Lingkunan Pemerintah Kota Pekanbaru Provinsi Riau termasuk Dinas Kesehatan Kota Pekanbaru, dikarenakan peraturan walikota tersebut tidak mengatur bagian bidang perencanaan, sehingga perencanaan juga dilakukan oleh bub bagian umum dan kepegawaian.

Melalui simpulan hasil penelitian di atas, maka peneliti ingin menyampaikan beberapa saran. Adapun saran yang dimaksud adalah sebagai berikut :

1. Perubahan kurikulum membuktikan bahwa pembaharuan pendidikan tidak pernah berakhir. Keberhasilan implementasi kurikulum sangat dipengaruhi oleh kemampuan guru yang akan menerapkan dan mengaktualisasikan kurikulum tersebut. Kemampuan guru tersebut terutama berkaitan dengan pengetahuan dan kemampuan serta tugas yang dibebankan kepadanya.

2. Tidak jarang kegagalanimplementasi kurikulum disebabkan oleh kurangnya pengetahuan, keterampilan dan kemampuan guru dalam memahami tugas-tugas yang harus dilaksanakan. Berbagai upaya telah dilakukan untuk meningkatkan mutu pendidikan, namun masih saja terus berupaya agar mutu pendidikan meningkat. Apa yang telah dicapai bukan berarti mutu pendidikan meningkat, namun apa yang meningkat itu masih perlu untuk ditingkatkan lagi.

3. Perangkat keras berupa sarana prasarana terus ditingkatkan pengadaannya, baik jumlah maupun kualitasnya. Perangkat lunak berupa kurikulum, pengadaan guru, dan penataran guru terusmenerus dilakukan. Namun, manusia memang jauh dari kesempurnaan, apa yang dilakukan itu ibarat tiada gading yang tak retak. Tidak ada metode pendidikan yang terbaik. Semua metode pendidikan ada yang positif dan ada pula negatifnya.Namun, apapun yang dilakukan pasti memilih yang terbaik. Saran yang diberikan kepada guru sebaiknya guru bahasa Inggris harus mampu merancang pembelajaran yang baik yang meliputi perencanaan, penggunaan teknik, dan media pembelajaran yang diperlukan agarpembelajaran lebih efektif.

Selain iu perlu diadakan penelitian lanjutan untuk peningkatan proses pembelajaran Peningkatan Minat Belajar Bahasa Inggris Siswa yang berfokus pada kompetensi lain seperti speaking, writing dan reading agar dapat mengembangkan profesinya dan mampu berkompetisi dalam membuat media pembelajaran yang lebih menarik lagi sehingga siswa lebih bersemangat dalam belajar. Demikian pula, guur sebaiknya dapat mengembangkan profesinya dan mampu berkompetisi serta berlomba-lomba untuk berprestasi sehingga dapat menguntungkan semua fihak, baik sekolah maupun guru yang bersangkutan, dan khususnya lagi anak didik yang akan merasakan dampaknya secara langsung.

\section{DAFTAR PUSTAKA}

[1]. Sikula, Andrew F., Personalia Administration and Human Resources Management. London: John Wiley and Sons, 1981.

[2]. Milkovich, George T, and Boudreau, John W. 1991. Human Resource Management. Fifth Edition. Boston : Allyn and Bacon.

[3]. Moekijat, 1991. Manajemen Kepegawaian. Cetakan Ketujuh. Bandung : Mandar Maju. 
[4]. Notoatmodjo, Soekidjo. 2003. Pengambangan Sumber Daya Manusia. Asdi Mahasatya, Jakarta.

[5]. Notoatmodjo, Soekidjo. 2003. Ilmu Kesehatan Masyarakat, Prinsip-Prinsip Dasar. PT. Rineka Cipta. Jakarta

[6]. WHO. 1990. Report of Study Group. Coordinated Health and Human Resources Development. World Health Organization Technical Report Series 801, Geneva.

[7]. Manullang. M. 2004. Manajemen Personalia. Edisi Ketiga. Gadjah Mada University Press, Yogyakarta.

[8]. Saputra, T. (2018). Capaian Pelayanan Kesehatan Dasar Di Kota Pekanbaru. Jurnal Ilmu Sosial, 16(1), 47-57.

[9]. SK Mendagri No. 23 Tahun 1994, Tentang Pedoman Organisasi dan Tata Kerja Puskesmas.

[10]. Peraturan Walikota Pekanbaru No. 18 tahun 2008 tentang rincian, fungsi, dan tata kerja dinas dilingkunan Pemerintah Kota Pekanbaru Provinsi Riau.

[11]. Peraturan Pemerintah Nomor 32 tahun 1996 tentang Tenaga Kesehatan.

[11]. Kepmenkes No.850/Menkes/SK/XII/2000 Tahun 2000 antara lain mengatur tentang kebijakan perencanaan tenaga kesehatan.

[12]. Kepmenkes No. 81/Menkes/SK/I/2004 Tahun 2004 mengatur tentang Pedoman Penyusunan Perencanaan Sumberdaya Kesehatan di tingkat provinsi, kabupaten/kota, serta rumah sakit. 